\title{
Assessment of the Potential Implementation of Solar Energy Generation in State Schools in Curitiba/PR
}

\author{
Juliano da Silva Pereira ${ }^{{ }^{*}}$; Daniele Abe Ribeiro ${ }^{1}$; Francielle Henrique Lucena ${ }^{1}$; Jair \\ Urbanetz Júnior, 1,2 \\ ${ }^{1}$ Programa de Pós-Graduação em Engenharia Civil, Universidade Tecnológica Federal do Paraná, Curitiba, Brasil; \\ ${ }^{2}$ Programa de Pós-Graduação em Sistemas de Energia, Universidade Tecnológica Federal do Paraná, Curitiba, \\ Brasil.
}

\begin{abstract}
Solar energy as a form of electric power generation is gaining ground in Brazil, being the subject of worldwide discussions on sustainability. The electric energy, a right of all citizens, represents a consumption of natural resources on a large scale. State schools in Paraná invested more than $R \$ 46$ million to guarantee electricity and thus provide essential running conditions to the system in 2016. Through open data, 15 schools from "Regional Administrativa do Cajuru", in Curitiba/PR, were evaluated in consumption and expenses of electric energy from January to May of 2017 and a solar photovoltaic system was dimensioned to supply the demand of each school. From that, it was estimated the total saving from the electricity that would no longer be spent on electricity which could be directed to other educational programs and projects of interest to the community towards sustainability within the school. The savings estimated totalized more than $R \$ 435$ thousand annually.
\end{abstract}

Keywords: Photovoltaic Solar Energy; Renewable energy; Education for Sustainability; State Schools; Public Administration.

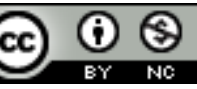

*Author of correspondence: julianosp.pereira@gmail.com 


\section{INTRODUCTION}

Since April 2012, when the Agência Nacional de Energia Elétrica - ANEEL [1] published its Resolution $\mathrm{n}^{\circ} 482$, the first to regulate the policies on energy credit for distributed generation in Brazil, there was an expressive growth in the electrical energy yield through photovoltaic systems.

However, according to the ANEEL`s Banco de Informações de Geração [2], those systems represent only $0.04 \%$ of the total amount of the Brazilian electrical power generation. Currently, $71.82 \%$ and $28.18 \%$ account for its renewable and non-renewable sources, from which $64.72 \%$ of the total supply comes from hydric sources. Therefore, and also considering the recent events of energy rationing due to the droughts in some power plants reservoirs, it is clear that the need for energy supply diversification from renewable sources ought to be greatly encouraged.

Thus, it is also intended to explore the sustainability in its three pillars - environmental, economic and social - reason why the adoption of grid connected PV systems for power supply in public schools of the State of Paraná.

The use of electric power through PV systems does not contribute to Greenhouse Gas Emissions, during energy generation [3]. Also, as a result of its modular characteristic, the PV systems can be used in the urban area, creating the proximity between the generation source and the consumer unit, thus reducing transmission losses.

Last but not least, the implementation of a photovoltaic system can take a short period of time, if compared to other renewable energy sources, as power plants, for example [4].

Weather conditions in Brazil enhance the potential regarding the use of solar photovoltaic systems. The national standard NBR 10899 defines solar irradiance as the rate by which solar irradiation occurs in a surface, by a unit area of the surface, usually measured in watt per square meter $\left(\mathrm{W} / \mathrm{m}^{2}\right)$ [5]. The annual average solar irradiation in Brazil is $1,986 \mathrm{kWh} / \mathrm{m}^{2} /$ year, while Germany, world leader in installed capacity of gridconnected solar photovoltaic systems, has only $1,251 \mathrm{kWh} / \mathrm{m}^{2}$ year.

Because of the current economic scenario in Brazil a lot of retrenchments from the government have been made, affecting all public domains, including the educational system. According to the online database from the Secretaria de Educação do Estado do Paraná - SEED, the amount spent with electrical power in all state schools of Parana in the year of 2016 was of $\mathrm{R} \$ 46,843.046 .00$, corresponding to 208,375 GWh [6] consumption.

There are studies related to the feasibility of the use of photovoltaic power in schools in countries with lower solar irradiation than Brazil. It is generally agreed that due to the fact that the low-rise typology of most of these school buildings allow enough non shaded areas to generate power to its self-sufficiency, which might not be viable to all urbanized areas.

In 2015, Brazil Greenpeace Organization was responsible for the implementation of a solar photovoltaic system in a Municipal School located in the State of Minas Gerais. After one year running the system, a 70\% saving in the energy bill was verified. The economy is reallocated to fund educational projects in the school, including extracurricular activities. Nonetheless, the users, especially the teachers, believe that the main importance of the project was beyond the economic factor, emphasizing the knowledge that the subject brings and how it can be explored and applied in the learning process of the students [7].

This NGO has been working institutionally in scaling up the use of solar power systems. The outcome of this action was the public investment of $\mathrm{R} \$ 2.6$ million in the year of 2017 to the installation of PV systems in about 40 Municipal Schools distributed through five States: Pará, Rio de Janeiro, Espírito Santo, Piauí and Goiás [8]. The 
installation is expected to happen in the second semester of this year, although no technical data on the systems have been released until the present moment.

As a socioeconomic impact it is still possible to mention the creation of both direct and indirect jobs, consequence of the use of PV power. It is foreseen that this sector will be responsible for the employment of 100 thousand workers until 2020 [9]. This information supports and evidences the need for the knowledge dissemination through the use of this technology in elementary education, not segregating it inside the academy and to specific sectors.

Thereby, to assist the potential of the photovoltaic energy generation implementation in State Schools and estimate its impacts on sustainability in education for the students, a sample of 15 schools belonging to the Administração Regional do Cajuru was evaluated.

The general data of these schools as well as those regarding the students, such as number of classes and enrollments were assessed. Also, the information about the consumption and the cost of electrical energy of the months January - May 2017 was collected. The potential for the implementation of the photovoltaic solar system was verified for 14 of these schools and a total saving of over $\mathrm{R} \$ 435$ thousand was estimated annually, which represents the amount spent on the electricity bills.

\section{MATERIALS AND METHODS}

The methodology used in this article consists of bibliographic and documental research, aiming to lay the theoretical and technical foundation for this research [10]. The State schools were chosen due to their public administration. From the total amount of 163 State schools, 15 were picked as the sample. Those represent the schools located in the Administração Regional do Cajuru. This Regional was selected by the fact that this location has the largest number of homes with 2,616 people living with the lowest monthly nominal wage of $\mathrm{R} \$ 70$, which is considered as extreme poverty [11]. The open data from these schools were collected through the online system "Consulta Escolas" made available by SEED [6], which contains detailed information about the schools, such as name, neighborhood, address, number of classes and enrollments. Data related to the energy consumption and the cost of the electricity bills from all 15 units from January to May 2017 were also collected.

The assessment of the electric energy consumption didn't take into account the figures of tariff flag and public lighting. All the evaluated schools are considered as low voltage energy consumers (LV) considered in the tariff group as "B3 conventional". Therefore, they don't have contracted demand, nor have they a differentiation in the peak and offpeak tariff. The measurement units used in the analysis were the kilowatt hour $(\mathrm{kWh})$, for the energy consumption, and the Real $(\mathrm{R} \$)$, which is the currency in Brazil. All data were tabulated and analyzed.

\section{RESULTS}

In the data analysis regarding the consumption $(\mathrm{kWh})$ and the cost of electric energy $(\mathrm{R} \$)$, for each school assessed, the value for the kilowatt hour $(\mathrm{R} \$ / \mathrm{kWh})$ was calculated. That was obtained from dividing the cost of the electricity bill by the energy consumption. It is possible to observe a variation of the monthly tariff for each school, which however, for calculation purpose, was considered as the average value, as a matter of simplification.

After this evaluation, the Professor Elysio Vianna State School, from the Guabirotuba neighborhood, wasn't take into account because it did not have any data available regarding the electric energy consumption for the period of time assessed - from January 
to May 2017. Also, the data from February from the República Oriental do Uruguai State School and the one from February and March from Santa Rosa State School were not registered at the "School Consultation" online system, so these months were dismissed from the analysis as well.

Next, the average monthly consumption $(\mathrm{kWh})$ from each school and its respective cost of the average monthly tariff $(\mathrm{R} \$ / \mathrm{kWh})$, disregarding the months when the data were not registered, are shown in Table 1.

Table 1 - Unitary and Average kWh values by School

\begin{tabular}{|c|c|c|c|c|c|c|}
\hline School & $\begin{array}{l}\text { Month } \\
\text { (2017) }\end{array}$ & $\begin{array}{c}\text { Consumption } \\
(\mathbf{k W h})\end{array}$ & $\begin{array}{c}\text { Energy Bill } \\
\text { Cost (R\$) }\end{array}$ & $\begin{array}{c}\text { Unitary Cost } \\
(\mathbf{R} \$ / \mathbf{k W h})\end{array}$ & $\begin{array}{c}\text { Average } \\
\text { kWh } \\
\text { Value }\end{array}$ & $\begin{array}{l}\text { Average } \\
\text { R } \$ / \mathbf{k W h}\end{array}$ \\
\hline \multirow{5}{*}{$\begin{array}{l}\text { Senhorinha de } \\
\text { Moraes Sarmento }\end{array}$} & January & 14,880 & $3,269.78$ & 0.22 & \multirow{5}{*}{25,264} & \multirow{5}{*}{0.17} \\
\hline & February & 16,880 & $3,720.51$ & 0.22 & & \\
\hline & March & 30,720 & $4,535.60$ & 0.15 & & \\
\hline & April & 36,480 & $3,659.61$ & 0.10 & & \\
\hline & May & 27,360 & $3,932.05$ & 0.14 & & \\
\hline \multirow{5}{*}{$\begin{array}{l}\text { Deputado Olivio } \\
\text { Belich }\end{array}$} & January & 5,826 & $1,280.21$ & 0.22 & \multirow{5}{*}{11,779} & \multirow{5}{*}{0.17} \\
\hline & February & 6,442 & $1,420.26$ & 0.22 & & \\
\hline & March & 13,998 & $2,067.44$ & 0.15 & & \\
\hline & April & 18,796 & $1,854.60$ & 0.10 & & \\
\hline & May & 13,833 & $2,005.71$ & 0.14 & & \\
\hline \multirow{5}{*}{$\begin{array}{c}\text { Professor Nilo } \\
\text { Brandao }\end{array}$} & January & 5,200 & $1,142.66$ & 0.22 & \multirow{5}{*}{12,096} & \multirow{5}{*}{0.15} \\
\hline & February & 9,960 & $1,463.03$ & 0.15 & & \\
\hline & March & 13,680 & $2,019.44$ & 0.15 & & \\
\hline & April & 18,080 & $1,829.12$ & 0.10 & & \\
\hline & May & 13,560 & $1,916.95$ & 0.14 & & \\
\hline \multirow{5}{*}{$\begin{array}{c}\text { República Oriental do } \\
\text { Uruguai }\end{array}$} & January & 6,566 & $1,442.83$ & 0.22 & \multirow{5}{*}{8,536} & \multirow{5}{*}{0.15} \\
\hline & February & 0 & 0.00 & 0.00 & & \\
\hline & March & 8,058 & $1,190.31$ & 0.15 & & \\
\hline & April & 11,372 & $1,116.74$ & 0.10 & & \\
\hline & May & 8,148 & $1,186.66$ & 0.15 & & \\
\hline \multirow{5}{*}{ Santa Rosa } & January & 11,896 & $2,164.07$ & 0.18 & \multirow{5}{*}{24,106} & \multirow{5}{*}{0.14} \\
\hline & February & 0 & 0.00 & 0.00 & & \\
\hline & March & 0 & 0.00 & 0.00 & & \\
\hline & April & 43,572 & $4,429.31$ & 0.10 & & \\
\hline & May & 16,851 & $2,371.78$ & 0.14 & & \\
\hline \multirow{5}{*}{$\begin{array}{c}\text { Professora Maria } \\
\text { Aguiar Teixeira }\end{array}$} & January & 16,974 & $3,729.94$ & 0.22 & \multirow{5}{*}{22,099} & \multirow{5}{*}{0.17} \\
\hline & February & 10,414 & $2,296.33$ & 0.22 & & \\
\hline & March & 24,969 & $3,688.38$ & 0.15 & & \\
\hline & April & 34,768 & $3,414.23$ & 0.10 & & \\
\hline & May & 23,370 & $3,403.56$ & 0.15 & & \\
\hline \multirow{5}{*}{ Anibal Khury Neto } & January & 23,196 & $5,097.18$ & 0.22 & \multirow{5}{*}{27,521} & \multirow{5}{*}{0.17} \\
\hline & February & 17,872 & $3,936,89$ & 0.22 & & \\
\hline & March & 29,019 & $4,282.22$ & 0.15 & & \\
\hline & April & 40,464 & $4,113.36$ & 0.10 & & \\
\hline & May & 27,054 & $3,807.84$ & 0.14 & & \\
\hline \multirow{3}{*}{ Alfredo Parodi } & January & 12,328 & $2,709.00$ & 0.22 & \multirow{3}{*}{15,128} & \multirow{3}{*}{0.17} \\
\hline & February & 1,480 & 325.97 & 0.22 & & \\
\hline & March & 16,935 & $2,498.66$ & 0.15 & & \\
\hline
\end{tabular}

Cont. 
Table 1 - Unitary and Average kWh values by School (Cont.)

\begin{tabular}{|c|c|c|c|c|c|c|}
\hline School & $\begin{array}{l}\text { Month } \\
(2017)\end{array}$ & $\begin{array}{c}\text { Consumption } \\
(\mathrm{kWh})\end{array}$ & $\begin{array}{c}\text { Energy Bill } \\
\text { Cost }(\mathbf{R} \$)\end{array}$ & $\begin{array}{c}\text { Unitary Cost } \\
\text { (R\$/kWh) }\end{array}$ & $\begin{array}{c}\text { Average } \\
\text { kWh } \\
\text { Value }\end{array}$ & $\begin{array}{l}\text { Average } \\
\text { R\$/kWh }\end{array}$ \\
\hline & April & 26,164 & $2,672.39$ & 0.10 & & \\
\hline & May & 18,735 & $2,625.37$ & 0.14 & & \\
\hline \multirow{5}{*}{ Conselheiro Carrão } & January & 11,440 & $2,513.87$ & 0.22 & \multirow{5}{*}{15,680} & \multirow{5}{*}{0.17} \\
\hline & February & 5,360 & $1,180.36$ & 0.22 & & \\
\hline & March & 19,800 & $2,920.55$ & 0.15 & & \\
\hline & April & 24,160 & $2,492.29$ & 0.10 & & \\
\hline & May & 17,640 & $2,461.03$ & 0.14 & & \\
\hline \multirow{5}{*}{ São Paulo Apóstolo } & January & 12,474 & $2,741.09$ & 0.22 & \multirow{5}{*}{15,991} & \multirow{5}{*}{0.17} \\
\hline & February & 12,790 & $2,816.60$ & 0.22 & & \\
\hline & March & 5,244 & 761.11 & 0.15 & & \\
\hline & April & 28,548 & $2,944.96$ & 0.10 & & \\
\hline & May & 20,898 & $2,915.56$ & 0.14 & & \\
\hline \multirow{5}{*}{$\begin{array}{l}\text { Professor Máximo } \\
\text { Atílio Asinelli }\end{array}$} & January & 4,024 & 884.23 & 0.22 & \multirow{5}{*}{11,152} & \multirow{5}{*}{0.17} \\
\hline & February & 3,432 & 755.65 & 0.22 & & \\
\hline & March & 13,341 & $1,980.79$ & 0.15 & & \\
\hline & April & 16,460 & $1,709.16$ & 0.10 & & \\
\hline & May & 18,504 & $2,564.24$ & 0.14 & & \\
\hline \multirow{5}{*}{ Pio Lanteri } & January & 6,804 & $1,495.12$ & 0.22 & \multirow{5}{*}{12,469} & \multirow{5}{*}{0.17} \\
\hline & February & 4,868 & $1,071.24$ & 0.22 & & \\
\hline & March & 15,600 & $2,299.65$ & 0.15 & & \\
\hline & April & 20,584 & $2,162.38$ & 0.11 & & \\
\hline & May & 14,487 & $1,976.44$ & 0.14 & & \\
\hline \multirow{5}{*}{$\begin{array}{c}\text { Paulina Pacifico } \\
\text { Borsari }\end{array}$} & January & 3,742 & 822.28 & 0.22 & \multirow{5}{*}{7,608} & \multirow{5}{*}{0.17} \\
\hline & February & 3,772 & 830.31 & 0.22 & & \\
\hline & March & 8,457 & $1,247.03$ & 0.15 & & \\
\hline & April & 12,300 & $1,286.16$ & 0.10 & & \\
\hline & May & 9,768 & $1,345.05$ & 0.14 & & \\
\hline \multirow{5}{*}{$\begin{array}{c}\text { Professor Elysio } \\
\text { Vianna }\end{array}$} & January & 0 & 0.00 & 0.00 & \multirow{5}{*}{-} & \multirow{5}{*}{-} \\
\hline & February & 0 & 0.00 & 0.00 & & \\
\hline & March & 0 & 0.00 & 0.00 & & \\
\hline & April & 0 & 0.00 & 0.00 & & \\
\hline & May & 0 & 0.00 & 0.00 & & \\
\hline \multirow{5}{*}{$\begin{array}{l}\text { Professor Julio } \\
\text { Mesquita }\end{array}$} & January & 8,240 & $1,810.69$ & 0.22 & \multirow{5}{*}{14,240} & \multirow{5}{*}{0.17} \\
\hline & February & 10,960 & $2,412.62$ & 0.22 & & \\
\hline & March & 11,520 & $1,698.69$ & 0.15 & & \\
\hline & April & 23,200 & $2,425.95$ & 0.10 & & \\
\hline & May & 17,280 & $2,368.13$ & 0.14 & & \\
\hline
\end{tabular}

Source: Adapted from SEED-PR ${ }^{6}$ 
The power of a PV system was calculated according to the Equation 1.

$P_{P V}=\frac{E \cdot G}{H_{T O T} \cdot P R}$
Where: $E$ - daily energy load demand (Wh/day); $G$ - solar irradiance in STC conditions $\left(\mathrm{Wh} / \mathrm{m}^{2}\right) ; H_{T O T}$ - solar incident irradiation in the surface of the $P V$ modules $\left(\mathrm{kWh} / \mathrm{m}^{2}\right.$.day); $P R$ - performance ratio

The daily energy load demand (E) was calculated considering the monthly average consumption of each School and is presented in Table 4.

The solar irradiance in STC conditions $(\mathrm{G})$ is $1,000 \mathrm{Wh} / \mathrm{m}^{2}$. As recommended by Pinho and Galdino [12], in order to achieve the optimal solar electric generation throughout the year, the tilt angle of the photovoltaic array system design should be the same as the local latitude and it should be oriented facing the equatorial line.

Curitiba is located at latitude $25^{\circ} 25^{\prime}$ South; longitude $49^{\circ} 16^{\prime}$ West. Therefore, to calculate the solar incident irradiation in the surface of the PV modules $\left(\mathrm{H}_{\mathrm{TOT}}\right)$ it was established that all the array systems would be installed facing north with a $25^{\circ}$ inclination. In the analysis it was considered that there would be no shaded areas in the systems during operating time.

The average irradiation data for the inclined plane at $25^{\circ}$ facing north was collected from the software SunData [13], resulting in a $4.62 \mathrm{kWh} / \mathrm{m}^{2} / \mathrm{day}$. The performance ratio (PR) adopted was 0.75 .

Therefore, the power of the photovoltaic system for each school was calculated using Equation 1.

For dimensioning the PV system, the calculation was made considering the model JKM320PP from Jinko Solar, a polycrystalline module with 72 cells, an output of 320 Wp and an efficiency of $16.49 \%$ under STC conditions.

Then, it was verified the area necessary to the installation of each system, according to the size of the array of the modules, and for that Equation 2 was used [14].

$n_{p}=\frac{P_{P V}}{A_{m} * 1000}$

Where: $n_{p}$ - conversion efficiency (\%); $P_{P V}$ - power of the system to be installed

$(\mathrm{kWp}) ; A_{m}$-photovoltaic module required area $\left(\mathrm{m}^{2}\right)$

To verify if the area available in each school roof was big enough to fit the photovoltaic module area $\left(\mathrm{A}_{\mathrm{m}}\right)$, the distance measurement tool from Google Maps was applied. All schools presented area availability for the system, as shown in Table 2.

Next, the total annual amount paid by the schools regarding the electricity consumption was estimated using Equation 3.

$V_{a}=T_{m m} * C_{m m} * n$

Where: - annual value (R\$); $T_{m m}-$ mean monthly tariff $(R \$ / k W h) ; C_{m m}-$ mean monthly consumption $(\mathrm{kWh}) ; n-$ number of months $=12$

The results in Table 2 refer to the power of each PV system, as well as the area required to install it and the available roof area, along with the financial resources destined to pay for the electricity bill, estimated for a whole year, which are considered as the savings. 
Table 2 - PV system power, $\mathrm{A}_{\mathrm{m}}$ - roof area required, roof area available and annual saving estimation

\begin{tabular}{|c|c|c|c|c|}
\hline School & $\mathbf{P}_{\mathrm{PV}}(\mathbf{k W p})$ & $\begin{array}{c}\text { Roof area } \\
\text { required }\left(\mathbf{m}^{2}\right)\end{array}$ & $\begin{array}{c}\text { Roof area } \\
\text { available }\left(\mathbf{m}^{2}\right)\end{array}$ & Annual Saving (R\$) \\
\hline Senhorinha de Moraes Sarmento & 243 & 1,471 & 3,320 & $50,436.81$ \\
\hline Deputado Olivio Belich & 113 & 686 & 2,048 & $23,508.14$ \\
\hline Professor Nilo Brandão & 116 & 704 & 2,438 & $21,969.88$ \\
\hline República Oriental do Uruguai & 82 & 497 & 986 & $15,654.16$ \\
\hline Santa Rosa & 231 & 1,403 & 2,152 & $40,915.28$ \\
\hline Professora Maria Aguiar Teixeira & 212 & 1,286 & 1,776 & $44,116.95$ \\
\hline Anibal Khury Neto & 264 & 1,602 & 2,300 & $54,821.63$ \\
\hline Alfredo Parodi & 145 & 881 & 1,957 & $30,128.86$ \\
\hline Conselheiro Carrão & 151 & 913 & 1,330 & $31,239.63$ \\
\hline São Paulo Apóstolo & 153 & 931 & 1,914 & $31,768.26$ \\
\hline Professor Máximo Atílio Asinelli & 107 & 649 & 1,710 & $22,236.74$ \\
\hline Pio Lanteri & 120 & 726 & 1,816 & $24,798.32$ \\
\hline Paulina Pacifico Borsari & 73 & 443 & 1,300 & $15,147.23$ \\
\hline Professor Elysio Vianna & - & - & - & - \\
\hline Professor Julio Mesquita & 137 & 829 & 1,124 & $28,329.87$ \\
\hline & & & TOTAL $(\mathrm{R} \$)$ & $435,071.76$ \\
\hline
\end{tabular}

Source: The authors

Thence, in the case of the installation of the PV systems, considering the whole demand would be supplied by it, the values set out would no longer be used to pay for electricity bills. The estimated amount for the total savings in present currency is $\mathrm{R} \$ 435,071.76 \mathrm{a}$ year, which corresponds to an average annual saving of $\mathrm{R} \$ 29.90$ and $\mathrm{R} \$ 863.88$, per student and per class, respectively. This represents a relief of $2.684 \mathrm{GWh}$ from the grid demand, considering only the 14 schools that were assessed, out of the potential 163 others, run by the government, only in the city of Curitiba.

The average power of the photovoltaic systems calculated for the installation is 150 $\mathrm{kWp}$. According to the Greener report [15], the average unitary price for a Wp for systems of $150 \mathrm{kWp}$ is $\mathrm{R} \$ 4.31 \mathrm{R} \$ / \mathrm{Wp}$. In this way, an estimation for the average cost of each system is around $\mathrm{R} \$ 646,500.00$. The Empresa de Pesquisa Energética - EPE [16] considers the yearly maintenance cost of a solar photovoltaic system to be low, not over $1 \%$ of the total amount of its implementation value. Thus, in this case, the annual average maintenance cost for all the systems would be under $\mathrm{R} \$ 6,465.00$, per school.

\section{DISCUSSION}

By incorporating the PV systems to the assessed Schools, it is intended to reduce the electric energy demand on the part of the State, relieving the demand in the Brazilian interconnected electric system. Considering the future scenario around 2050, when energy consumption is foreseen to almost double, going from $600 \mathrm{TWh} /$ year to 1,024 $\mathrm{TWh} /$ year, according to EPE [17], every measure towards electric demand reduction should be considered.

Along with that, these installations would provide approximately $\mathrm{R} \$ 435$ thousand in savings. This amount could be redirected to provide for the implementation of sustainability educational programs within the Schools, as the project developed by Greenpeace Brazil in 2015 and 2017.

Because it is a solution involving the public sector, it is well known that the money saved with electricity cannot simply be redirected to educational programs. However, there is a strong need of an effort from the part of the policy makers and government authorities to ensure these resources are invested in education for sustainability in the Schools. 


\section{CONCLUSION}

The regulation of the PV systems collaborated to the exponential growth in the number of units installed in Brazil in the last few years. The renewable and alternative sources of energy have become increasingly attractive for sustainability in its three pillars: environmental, economic and social.

Grid-connected solar photovoltaic systems for power supply do not contribute to Greenhouse Gas Emissions during power generation; still, they provide the possibility for reduction of the cost of energy; they create job opportunities both directly and indirectly; besides the other social and cultural aspects, due to the contact with technology.

The potential for the implementation of a PV system in 14 schools located at the Administração Regional do Cajuru, comprised by the neighborhoods of Cajuru, Capão da Imbuia, Jardim das Américas and Uberaba, was attested in the present study. With the installation of this technology an annual saving of over R $\$ 435$ thousand was predicted for the current electrical consumption. In the case of the State of Paraná, one of the four remaining State that is still keeping the taxes (ICMS) charged over the energy injected into the grid. That means that the saving costs could be even greater if the tax was suppressed, like in the other 23 Brazilian States.

The amount that would be no longer spent with electricity bills could be invested in educational programs and extracurricular activities within the schools, based on sustainability principles.

The online data base had only made a few months of information available, from January to May 2017. For a more consistent analysis, a scenario with a larger historic series of data should be made available. A 3-year series, or at least a 12 month period, is usually considered to evaluate the demand curve and to optimize the sizing of the system. Yet, regarding the design of the array of the modules, as a suggestion for further research, it is recommended to verify the real slope of the roofs and their orientation towards north, as well as the existence of shaded areas over it. Also, there is a need to create an index to assess the consumption within the schools.

All considered, a great potential was noticed among this sector, so as schools can achieve their self-sufficiency and thus help mitigate social and environmental impacts of energy generation. Although these two aspects of sustainability are hard to measure, if compared to the economic pillar, they should be taken into consideration as variables to the future analysis of technical solutions.

\section{REFERENCES}

1- Agência Nacional De Energia Elétrica (Brazil). Resolução n . 482, de 17 de abril de 2012. Estabelece as condições gerais para o acesso de micro geração e minigeração distribuída aos sistemas de distribuição de energia elétrica, o sistema de compensação de energia elétrica, e dá outras providências. Diário Oficial; 2012 Apr 19.

2- Agência Nacional De Energia Elétrica (Brazil). BIG: banco de informações de geração: fontes de energia exploradas no Brasil [Internet]. 2017 [cited 2017 Jul 3]. Available from: http://www2.aneel.gov.br/aplicacoes/capacidadebrasil/capacidadebrasil.cfm.

3- Campos HMVB. Geração distribuída de energia solar fotovoltaica na matriz elétrica de Curitiba e região: um estudo de caso [dissertation]. PPGEC UTFPR; 2015.

4- Alencar CA, Urbanetz Junior J. Usinas solares fotovoltaicas no brasil: panorama atual e perspectivas futuras. In: 12th IEEE/IAS International Conference on Industry Applications, 2016. 2016 Nov 20-23, Curitiba: INDUSCON; 2016.

5- Associação Brasileira de Normas Técnicas (Brazil). NBR 10899 - Energia solar fotovoltaica. Rio de janeiro; 2013. 
6- Secretaria do Estado da Educaçao do Paraná (Brazil). SEED em números: Consumo Total de Energia Elétrica das Escolas do Estado por Mês - Ano de 2016 [Internet]. 2017 [cited 2017 Jun 25]. Available from: http://www4.pr.gov.br/escolas/numeros/frame_geralluz.jsp?ano=2016 7- Greenpeace. Evento comemora um ano de painéis solares em escola de Uberlândia [Internet]. 2016 Apr 16 [cited 2017 Jun 18]. Available from:

http://www.greenpeace.org/brasil/pt/Noticias/Evento-comemora-um-ano-de-paineis-solaresem-escola-de-Uberlandia/

8- Borges A. Energia solar começa a ganhar espaço em escolas públicas. 2017 Jan 16 [cited 2017 Jun 15]. In: O Estado de São Paulo [Internet]. Brasília, 2017. Available from: http://economia.estadao.com.br/noticias/geral,energia-solar-comeca-a-ganhar-espaco-emescolas-publicas, 10000100462

9- Benelli AC. Setor de energia solar promete criar 100 mil novos empregos no Brasil até 2020. 2016 Nov 16 [cited 2017 Jun 15]. In: Gazeta do Povo [Internet]. Curitiba, 2016. Available from: http://www.gazetadopovo.com.br/economia/energia-e-sustentabilidade/setor-de-energiasolar-promete-criar-100-mil-novos-empregos-no-brasil-ate-2020-

e11hokzez2v883qx8ipp0wfun

10- Gil AC. Como elaborar projetos de pesquisa. São Paulo: Atlas; 2010.

11- Instituto De Pesquisa E Planejamento Urbano De Curitiba (Brazil). Pobreza: Análise do Censo 2010. Curitiba: IPPUC, 2012 [Internet]. 2012 [cited 2017 Jun 26]. Available from: http://www.ippuc.org.br/

12- Pinho JT, Galdino MA. Manual de Engenharia para Sistemas Fotovoltaicos. Rio de Janeiro, RJ: CEPEL - CRESESB; 2014.

13- Centro de Referência para Energia Solar e Eólica Sérgio Brito (Brazil). Potencial Solar SunData, 2017 [Internet]. 2017 [cited 2017 Jun 25]. Available from: http://www.cresesb.cepel.br/index.php?section=sundata

14- Villalva MG. Energia Solar Fotovoltaica - Conceitos e Aplicações. São Paulo, 2015.

15- Greener. Análise do Mercado Fotovoltaico de Geração Distribuída - 2º Semestre de 2017 [Internet]. 2017 Jul [cited 2017 Jul 15]. Available from: http://www.greener.com.br/wpcontent/uploads/2017/07/anlise-estratgica-do-mercado-fotovoltaico-de-gerao-distribuda-2osemestre-2017-greener.pdf

16- Empresa de Pesquisa Energética (Brazil). Nota Técnica EPE: Análise da Inserção da Geração Solar na Matriz Elétrica Brasileira. Rio de Janeiro; 2012.

17- Empresa de Pesquisa Energética (Brazil). Nota Técnica DEA 13/14: Demanda de Energia 2050. Rio de Janeiro; 2014. 